\title{
Emerging trends in state finances in India: 1995-96 to 2011-12
}

\author{
Santosh Nandal, Annu \\ Department of Economics, Maharshi Dayanand University Rohtak, India \\ Email address: \\ santoshnandal@yahoo.in(S. Nandal),gahlawatannu18@gmail.com(Annu)
}

To cite this article:

Santosh Nandal, Annu. Emerging Trends in State Finances in India: 1995-96 to 2011-12. International Journal of Economics, Finance and Management Sciences. Vol. 1, No. 6, 2013, pp. 258-265. doi: 10.11648/j.jjefm.20130106.11

\begin{abstract}
Sharp deterioration in state finance during the last decade has been a matter of serious concern to policy makers in India. The deterioration in State finance is largely an outcome of the fact that in the fact of a limited resourcebase the states had to cope with a significant growth in their committed expenditure. Correcting the fiscal imbalances today is the single most important object of the new economic policy in India. The crucial issue therefore is to bring out improvement in State finance with a view to restructuring the expenditure in favour of development expenditure in order to enable a higher growth. The states took policy measures which helped them to avoid further worsening of their fiscal position to some extent. The Thirteenth Finance Commission has set a target of reducing fiscal deficit to 3\% of GDP for States latest by 2014-15. The present study attempts to bring out the emerging trends in state finances of India in recent years.
\end{abstract}

Keywords: State Finances, Fiscal Imbalances, Deficits

\section{Introduction}

According to federal system of India, the States have very crucial role in the process of overall economic development. State governments have been assigned large social and economic developmental responsibilities under the provision of Constitution of India. To carry out these responsibilities successfully, the state governments have to incur much expenditure.

State Finances is a comparative study of State Govt. Budgets. The study of state finances is very important in the present scenario because states play significant role in economic development. The finance is the sum total of economic relations in the process of which monetary fund of the state or economy are formed. The finance and financial policies of the state is an efficient instrument for the development of the economy. The growing importance of state finances in the macro economy is evident from the fact that the size of overall development expenditure of the states has always been higher than that of centre and this difference has got widened rather significantly in the 1990s. Assignment of functions and sources of finances among different tiers of the Government is crucial for the efficient organisation of any federal fiscal system. To enhance welfare gains, the lower level jurisdiction would have to provide all public services of a non-national character and thereby promote growth. The states have the primary responsibility to undertake tasks pertaining to developing social and economic infrastructure. However their ability to undertake such developmental functions is critically determined by their financial position. States are starved of funds to meet the essential investment needs in social and infrastructure sector. Large borrowings are restored to by several states just to meet the current expenditure.

\section{Objectives}

The objectives of the present study are as follows:

1. To study the aspect of fiscal imbalances of the States.

2. To analyse the trends in State finances in India.

\section{Research Methodology}

The present study is carried out to find the emerging trends in State finances in India. It is exclusively based on secondary data taken from various Issues on "State Finances" by Reserve Bank of India, Budget Documents of State Governments, and various Issues of Indian Public Finance Statistics. To portray the emerging trends of State finances, the present study analyses the State finances since 
1995-96 upto 2011-12. The statistical tools used for analysis of data are percentage method, mean, standard deviation, coefficient of variation, annual growth rate and chain index. The limitation of secondary data also applies on the study.

\section{Review of Literature}

A number of research studies have been undertaken by different researchers on State finances and related topics at national and international level. This section deals with the review of studies of State finances in India.

Rao, M. Govinda (1981) made an attempt to identify the determinant of tax revenue and non tax revenue expenditure in four states i.e. Karnataka, Kerala, Orissa and West Bengal towards making their medium term projections. The study also quantifies the effect of various economic and political factors on fiscal decisions of four states. The study found that fiscal decisions are essentially guided by the desire to maximize the length of their tenure by parties in power and are not influenced by their ideological doctrines.

Rao, M. Govinda (1992) examined the present state of public finance at the state level with a view of tracing the emerging in medium and long term. The objective of the paper was to identify the major problem areas and indicates policy initiative to tackle them. The study concluded that fiscal position in states calls for bold and decisive policy measures.

Bagchi, et.al (2002) in their article has discussed about the causes of fiscal indiscipline at the state level. Weakness of the system of inter-governmental fiscal relations has been cited as prime caused leading to fiscal indiscipline among states, which call for corrective measures.

Kochhar, K. (2004) examines India's fiscal imbalances in international perspective. The study also traces key developments in major macroeconomic variablesinflation, external balances, interest rates and growth with a view to examine the macroeconomic implications of the build-up in fiscal imbalances. The study found that India can no longer afford to be complacent about the impact of fiscal imbalances on the macro economy. The study concludes with the argument that the current confluence of positive economic developments affords a good opportunity to make a decisive and front-loaded start to correcting the large fiscal imbalances. Given the large infrastructure gap, the bulk of the increase in tax revenues so raised should be directed toward infrastructure needs.

Khan, M.A. and Hasan, M. (2006) made an attempt to analyse the fiscal reforms initiated at the state level. The paper deals with problems of fiscal imbalances of the State Governments, major trends and problems on the expenditure side, trends and problems on the revenue side and prospects and issues in fiscal improvements.

Srivastava, D. K. (2009) discussed the vertical and horizontal dimensions of fiscal transfer in four southern states i.e. Andhra Pradesh, Karnataka, Tamil Nadu, and
Kerala in the context of the ongoing deliberations of the Thirteenth Finance Commission. These states also show considerable intra-state inequalities in terms of economic activities as well as provision of essential services including health and education. The study revealed that the southern states have lost share in overall transfers as result of losing out both in terms of tax devolution and grants. The study concluded that there is a need to redesign transfers reflecting principle of equalization. The Thirteenth Finance Commission has to take this into account in making their assessments apart from the issues of compensation for losses in the initial years.

Vadra, R. (2010) studied the deteriorating trends in state finances of India for the time period ranging from 1990-91 to $2009-10(\mathrm{BE})$. The paper also examined as to what extent the recent reform measures taken by states are helpful in reducing the fiscal imbalances. The paper details the areas of reforms of states should focus on to impart efficiency and improve revenue productivity of revenues. The paper concluded that there is a need of strong political will and administrative competence and involvement of public in the reform process.

Srivastava, D.K. and Rao, C.B. (2011) examined the pattern of changes in states share in central taxes from the First to the Twelfth Finance Commission period. In addition, pattern of dependence of states on central transfers is also studied with respect to five groups of states, namely, high, middle and low income general category states and two groups of special category states and general category states. The analysis covers the period from 199091 to 2007-08. The study found that the dependence of the states on their share in central taxes has increased because of high buoyancy of total central taxes and a progressive increase in their share recommended by successive Finance Commissions. In terms of groups of states, the extent of dependence is relatively quite high for the special category states.

Dasgupta Zico (2012) made a study on the development expenditure of Indian States in the post liberalisation period. The study aimed at identifying the constraints which lead to declining development expenditure of states. It was observed that the development expenditure of states was about $12 \%$ of the GDP in 1980 s. It declined to 8 to $9 \%$ of GDP in post liberalisation period. The study concluded that the decline in development expenditure of states was due to dependency of states on centre to a large extent. It may be suggested that the states should be provided proper autonomy in their revenue mobilisation.

Balasubramanian, G. (2012) analysed the impact of central government transfers on tax efforts and expenditure behaviour of the state governments. The study was based on secondary data ranging from 1993-94 to 2007-08 for 15 major states of India. The study revealed that Finance Commission transfers discouraged the states to make efforts to increase their tax base. The state governments increased their revenue expenditure using the resource transfer from Finance Commissions. The study suggested 
that transfer should be based on fiscal performance to develop fiscal responsibility among states.

\section{Fiscal Imbalances in States}

It is useful to begin recounting the history of state finances by examining the profile of fiscal imbalances. Fiscal imbalances in the states are structural in nature. Expenditure has grown more in comparison to revenues and the differences between revenue and expenditure of states have been increasing. Three key fiscal parametersrevenue deficit, fiscal deficit and primary deficit measured relative to GDP indicate the extent of overall fiscal imbalances in the finances of the Union or State government during a specified period. Analysis of the data shows the deterioration of the revenue, primary as well as fiscal deficit of the states. Declining revenue-GDP ratio, slow growth of tax revenues, declining non-tax revenues, expanding expenditures, inequity and disincentives from central transfer are the major sources of fiscal imbalances in India. The problem of deterioration of fiscal health of states is particularly relevant in the context of less developed states where the Government will have to make significant investment for the development and maintenance of physical and social infrastructure. Many states have tried to overcome their immediate fiscal imbalances by taking structural adjustment loans from multilateral lending institutions. Notable among them, the states availing such facility are Andhra Pradesh, Karnataka and Uttar Pradesh from the World Bank and Gujarat and Madhya Pradesh from Asian Development Bank. Other states are also in the fray seeking loans from these institutions. Correcting the fiscal imbalances today is the single most important object of the new economic policy in India. While there has been a lot of discussion on the problem of fiscal imbalances and the need to undertake corrective measures by the Central Government. Fiscal health of the States is represented through Table-1. Table-1 shows the deficit of state governments of India during the period 1990-91 to 2011-12. The table shows the deficits (gross fiscal deficit, revenue deficit and primary deficit) as percentage of GDP. The gross fiscal deficit of state governments was 3.3 percent of GDP in 1990-91 which increased to high level of 4.6 percent in 1999-2000 and then declined to 1.8 percent in 2006-07 but then further increased to 2.2 percent in 2011-12 (BE). This increase in the fiscal deficit consists of rise in revenue deficit and primary deficit in 1999-2000. In relation to GDP, revenue deficit also increased from 0.9 percent in 1990-91 to a peak of 2.8 percent in $1999-2000$ and declined to -0.2 percent in 2011-12 (BE). It may be noted that the primary deficit of states was 1.8 percent in 1990-91 which increased to 2.3 percent in 1999-2000 and then declined to 0.6 percent in 2011-12 (BE).
Table1. Major Deficit Indicators of State Governments

(As a Percentage of GDP)

\begin{tabular}{|c|c|c|c|}
\hline Year & $\begin{array}{l}\text { Gross Fiscal } \\
\text { Deficit }\end{array}$ & $\begin{array}{l}\text { Revenue } \\
\text { Deficit }\end{array}$ & Primary deficit \\
\hline $1990-91$ & 3.3 & 0.9 & 1.8 \\
\hline $1991-92$ & 2.9 & 0.9 & 1.2 \\
\hline $1992-93$ & 2.8 & 0.7 & 1.0 \\
\hline 1993-94 & 2.4 & 0.4 & 0.5 \\
\hline $1994-95$ & 2.7 & 0.7 & 0.8 \\
\hline $1995-96$ & 2.6 & 0.7 & 0.8 \\
\hline $1996-97$ & 2.7 & 1.2 & 0.8 \\
\hline $1997-98$ & 2.8 & 1.1 & 0.9 \\
\hline 1998-99 & 4.2 & 2.5 & 2.2 \\
\hline $1999-2000$ & 4.6 & 2.8 & 2.3 \\
\hline $2000-01$ & 4.2 & 2.6 & 1.8 \\
\hline 2001-02 & 4.1 & 2.7 & 1.4 \\
\hline $2002-03$ & 4.1 & 2.3 & 1.3 \\
\hline 2003-04 & 4.4 & 2.3 & 1.5 \\
\hline 2004-05 & 3.3 & 1.2 & 0.7 \\
\hline $2005-06$ & 2.4 & 0.2 & 0.2 \\
\hline $2006-07$ & 1.8 & -0.6 & -0.4 \\
\hline $2007-08$ & 1.5 & -0.9 & -0.5 \\
\hline 2008-09 & 2.4 & -0.2 & 0.6 \\
\hline $2009-10$ & 2.9 & 0.5 & 1.2 \\
\hline 2010-11 (BE) & 2.6 & 0.3 & 0.9 \\
\hline 2010-11 (RE) & 2.7 & 0.3 & 1.0 \\
\hline 2011-12 (BE) & 2.2 & -0.2 & 0.6 \\
\hline
\end{tabular}

Note: BE - Budget Estimates RE - Revised Estimates

'-' signs indicates surplus in deficit indicators.

Source: Budget Documents of the State Governments and Reserve Bank Record

\section{Trends in Receipts and Expenditure of States}

The strength and weakness of State finances are seeded in the expenditure and revenue assignments provided for in the Constitution for the centre and states. A resource gap is natural outcome of these assignments as most resources with the centre and responsibilities with the states. This section examines the trends of both sides of balance sheet of the State Government's finances as receipts and expenditure heads which is explained with the help of time series data for States during the period from 1995-96 to 2011-12 (BE). 
Table2. Revenue Receipts of States

(Rs. in Crore)

\begin{tabular}{|c|c|c|c|c|c|c|c|}
\hline Year & $\begin{array}{l}\text { Tax Revenue } \\
\text { (i) }\end{array}$ & $\begin{array}{ll}\text { Non } & \text { Tax } \\
\text { Revenue (ii) }\end{array}$ & $\begin{array}{l}\text { Grants from } \\
\text { Centre (iii) }\end{array}$ & $\begin{array}{ll}\text { Transfer } & \text { from } \\
\text { Funds (iv) } & \\
\end{array}$ & $\begin{array}{l}\text { Revenue Receipts } \\
\text { ( i, ii ,iii, iv) }\end{array}$ & $\begin{array}{l}\text { Annual } \\
\text { Receipt } \\
\text { Rate }\end{array}$ & $\begin{array}{r}\text { Revenue } \\
\text { Growth }\end{array}$ \\
\hline 1995-96 & $\begin{array}{l}93085.03 \\
(70.65)\end{array}$ & $\begin{array}{l}17824.83 \\
(13.53)\end{array}$ & $\begin{array}{l}20744.22 \\
(15.74)\end{array}$ & $\begin{array}{l}111.07 \\
(0.08)\end{array}$ & $\begin{array}{l}131765.15 \\
(100 \%)\end{array}$ & - & \\
\hline 1996-97 & $\begin{array}{l}106331.59 \\
(72.53)\end{array}$ & $\begin{array}{l}15775.66 \\
(10.76)\end{array}$ & $\begin{array}{l}23335.75 \\
(15.91)\end{array}$ & $\begin{array}{l}1168.27 \\
(0.89)\end{array}$ & $\begin{array}{l}146611.27 \\
(100 \%)\end{array}$ & 11.26 & \\
\hline 1997-98 & $\begin{array}{l}121566.37 \\
(73.78)\end{array}$ & $\begin{array}{l}16597.25 \\
(10.07)\end{array}$ & $\begin{array}{l}25163.53 \\
(15.28)\end{array}$ & $\begin{array}{l}1449.69 \\
(0.87)\end{array}$ & $\begin{array}{l}164776.84 \\
(100 \%)\end{array}$ & 12.39 & \\
\hline 1998-99 & $\begin{array}{l}128641.78 \\
(74.62)\end{array}$ & $\begin{array}{l}17839.70 \\
(10.35)\end{array}$ & $\begin{array}{l}24213.93 \\
(14.04)\end{array}$ & $\begin{array}{l}1718.43 \\
(0.99)\end{array}$ & $\begin{array}{l}172413.84 \\
(100 \%)\end{array}$ & 4.63 & \\
\hline $1999-2000$ & $\begin{array}{l}146963.71 \\
(73.09)\end{array}$ & $\begin{array}{l}21394.38 \\
(10.64)\end{array}$ & $\begin{array}{l}31021.86 \\
(15.42)\end{array}$ & $\begin{array}{l}1714.97 \\
(0.85)\end{array}$ & $\begin{array}{l}201094.92 \\
(100 \%)\end{array}$ & 16.63 & \\
\hline 2000-01 & $\begin{array}{l}162157.68 \\
(73.12)\end{array}$ & $\begin{array}{l}20148.68 \\
(9.08)\end{array}$ & $\begin{array}{l}37430.69 \\
(16.88)\end{array}$ & $\begin{array}{l}2054.21 \\
(0.92)\end{array}$ & $\begin{array}{l}221791.26 \\
(100 \%)\end{array}$ & 10.29 & \\
\hline 2001-02 & $\begin{array}{l}180712.07 \\
(72.12)\end{array}$ & $\begin{array}{l}22640.34 \\
(9.11)\end{array}$ & $\begin{array}{l}42936.37 \\
(17.28)\end{array}$ & $\begin{array}{l}2211.90 \\
(0.89)\end{array}$ & $\begin{array}{l}248500.68 \\
(100 \%)\end{array}$ & 12.04 & \\
\hline 2002-03 & $\begin{array}{l}192363.44 \\
(72.99)\end{array}$ & $\begin{array}{l}24850.91 \\
(9.43)\end{array}$ & $\begin{array}{l}42560.23 \\
(16.14)\end{array}$ & $\begin{array}{l}3786.30 \\
(1.44)\end{array}$ & $\begin{array}{l}263560.88 \\
(100 \%)\end{array}$ & 6.06 & \\
\hline 2003-04 & $\begin{array}{l}225885.65 \\
(73.10)\end{array}$ & $\begin{array}{l}28767.50 \\
(9.32)\end{array}$ & $\begin{array}{l}49977.41 \\
(16.17)\end{array}$ & $\begin{array}{l}4357.06 \\
(1.41)\end{array}$ & $\begin{array}{l}308987.62 \\
(100 \%)\end{array}$ & 17.23 & \\
\hline 2004-05 & $\begin{array}{l}267876.80 \\
(74.42)\end{array}$ & $\begin{array}{l}29627.03 \\
(8.23)\end{array}$ & $\begin{array}{l}57167.64 \\
(15.89)\end{array}$ & $\begin{array}{l}5264.03 \\
(1.46)\end{array}$ & $\begin{array}{l}359935.50 \\
(100 \%)\end{array}$ & 16.48 & \\
\hline 2005-06 & $\begin{array}{l}316563.05 \\
(72.82)\end{array}$ & $\begin{array}{l}34476.12 \\
(7.93)\end{array}$ & $\begin{array}{l}77479.79 \\
(17.82)\end{array}$ & $\begin{array}{l}6243.02 \\
(1.43)\end{array}$ & $\begin{array}{l}434761.98 \\
(100 \%)\end{array}$ & 22.01 & \\
\hline 2006-07 & $\begin{array}{l}383547.06 \\
(71.11)\end{array}$ & $\begin{array}{l}53194.40 \\
(9.86)\end{array}$ & $\begin{array}{l}95793.10 \\
(17.76)\end{array}$ & $\begin{array}{l}6814.29 \\
(1.27)\end{array}$ & $\begin{array}{l}539348.85 \\
(100 \%)\end{array}$ & 24.05 & \\
\hline 2007-08 & $\begin{array}{l}423583.10 \\
(71.87)\end{array}$ & $\begin{array}{l}54266.95 \\
(9.20)\end{array}$ & $\begin{array}{l}107234.80 \\
(8.19)\end{array}$ & $\begin{array}{l}4326.56 \\
(0.74)\end{array}$ & $\begin{array}{l}589411.41 \\
(100 \%)\end{array}$ & 9.28 & \\
\hline 2008-09 & $\begin{array}{l}464683.00 \\
(71.28)\end{array}$ & $\begin{array}{l}55441.44 \\
(8.50)\end{array}$ & $\begin{array}{l}126944.33 \\
(19.48)\end{array}$ & $\begin{array}{l}4841.36 \\
(0.74)\end{array}$ & $\begin{array}{l}651910.13 \\
(100 \%)\end{array}$ & 10.60 & \\
\hline 2009-10 & $\begin{array}{l}543673.44 \\
(71.40)\end{array}$ & $\begin{array}{l}64678.01 \\
(8.60)\end{array}$ & $\begin{array}{l}150382.26 \\
(19.75)\end{array}$ & $\begin{array}{l}2633.44 \\
(0.35)\end{array}$ & $\begin{array}{l}761367.15 \\
(100 \%)\end{array}$ & 16.79 & \\
\hline 2010-11(RE) & $\begin{array}{l}696194.99 \\
(72.20)\end{array}$ & $\begin{array}{l}68507.34 \\
(7.10)\end{array}$ & $\begin{array}{l}196643.33 \\
(20.40)\end{array}$ & $\begin{array}{l}2798.97 \\
(0.30)\end{array}$ & $\begin{array}{l}964144.63 \\
(100 \%)\end{array}$ & 26.63 & \\
\hline 2011-12(BE) & $\begin{array}{l}822243.63 \\
(73.79)\end{array}$ & $\begin{array}{l}66571.10 \\
(5.98)\end{array}$ & $\begin{array}{l}222944.09 \\
(20.00)\end{array}$ & $\begin{array}{l}2552.54 \\
(0.23)\end{array}$ & $\begin{array}{l}1114311.36 \\
(100 \%)\end{array}$ & 15.57 & \\
\hline
\end{tabular}

Note: BE - Budget Estimates

RE - Revised Estimates

Figures in the parenthesis are percentages to total revenue receipts of states and calculated by the author.

Source: Various Issues of Indian Public Finance Statistics, Ministry of Finance.

Table-2 shows the growth in revenue receipts of the States over the period from $1990-91$ to $2011-12$. The total revenue receipts of the states have increased from Rs. 131765.15 crore in $1995-96$ to Rs. 1114311.36 crore in 2011-12 (BE). The contribution of tax revenue to total revenue receipts has been increasing from 70.65 percent in 1995-96 to 73.79 percent in 2011-12(BE). The percent share of non tax revenue was estimated at 5.98 percent in
2011-12 Budgets. Similarly, the grants from Centre to the States do not represent a healthy situation for state finances. Grants from Cent/re constitute only 20.0 percent of revenue receipts of the states. As far as transfer from funds concerned, it comprises only 0.23 percent of the revenue receipts of the states in 2011-12 (BE). Annual revenue receipt growth rate has increased from 11.26 percent in 1996-97 to 15.57 percent in 2011-12 (BE). 
Table3. Revenue Expenditure of States

(Rs. in Crore)

\begin{tabular}{|c|c|c|c|c|c|}
\hline Year & $\begin{array}{l}\text { Non Developmental } \\
\text { Expenditure (i) }\end{array}$ & $\begin{array}{l}\text { Developmental } \\
\text { Expenditure (ii) }\end{array}$ & $\begin{array}{l}\text { Transfer of Funds } \\
\text { (iii) }\end{array}$ & $\begin{array}{l}\text { Revenue Expenditure } \\
\text { (i, ii, iii) }\end{array}$ & $\begin{array}{l}\text { Annual } \\
\text { Revenue } \\
\text { Expenditure } \\
\text { Growth Rate }\end{array}$ \\
\hline 1995-96 & $\begin{array}{l}64392.62 \\
(45.84)\end{array}$ & $\begin{array}{l}76024.15 \\
(54.11)\end{array}$ & $\begin{array}{l}82.55 \\
(0.05)\end{array}$ & $\begin{array}{l}140499.32 \\
(100 \%)\end{array}$ & - \\
\hline 1996-97 & $\begin{array}{l}69595.48 \\
(42.78)\end{array}$ & $\begin{array}{l}90853.01 \\
(55.85)\end{array}$ & $\begin{array}{l}2228.10 \\
(1.37)\end{array}$ & $\begin{array}{l}162676.59 \\
(100 \%)\end{array}$ & 15.78 \\
\hline $1997-98$ & $\begin{array}{l}81247.38 \\
(44.77)\end{array}$ & $\begin{array}{l}97481.47 \\
(53.72)\end{array}$ & $\begin{array}{l}2749.88 \\
(1.51)\end{array}$ & $\begin{array}{l}181478.73 \\
(100 \%)\end{array}$ & 11.55 \\
\hline 1998-99 & $\begin{array}{l}95093.25 \\
(44.03)\end{array}$ & $\begin{array}{l}117032.57 \\
(54.18)\end{array}$ & $\begin{array}{l}3868.13 \\
(1.79)\end{array}$ & $\begin{array}{l}215993.95 \\
(100 \%)\end{array}$ & 19.01 \\
\hline $1999-2000$ & $\begin{array}{l}118338.24 \\
(46.43)\end{array}$ & $\begin{array}{l}133491.19 \\
(52.38)\end{array}$ & $\begin{array}{l}3028.58 \\
(1.19)\end{array}$ & $\begin{array}{l}254858.01 \\
(100 \%)\end{array}$ & 17.99 \\
\hline 2000-01 & $\begin{array}{l}129010.88 \\
(47.44)\end{array}$ & $\begin{array}{l}138415.82 \\
(50.90)\end{array}$ & $\begin{array}{l}4539.65 \\
(1.66)\end{array}$ & $\begin{array}{l}271966.3 \\
5(100 \%)\end{array}$ & 6.71 \\
\hline 2001-02 & $\begin{array}{l}150845.96 \\
(49.39)\end{array}$ & $\begin{array}{l}148946.77 \\
(48.77)\end{array}$ & $\begin{array}{l}5650.08 \\
(1.84)\end{array}$ & $\begin{array}{l}305442.81 \\
(100 \%)\end{array}$ & 12.30 \\
\hline 2002-03 & $\begin{array}{l}159605.85 \\
(50.23)\end{array}$ & $\begin{array}{l}151256.47 \\
(47.60)\end{array}$ & $\begin{array}{l}6918.17 \\
(2.17)\end{array}$ & $\begin{array}{l}317780.49 \\
(100 \%)\end{array}$ & 4.03 \\
\hline 2003-04 & $\begin{array}{l}181267.55 \\
(49.26)\end{array}$ & $\begin{array}{l}178882.46 \\
(48.60)\end{array}$ & $\begin{array}{l}7853.44 \\
(2.14)\end{array}$ & $\begin{array}{l}368003.45 \\
(100 \%)\end{array}$ & 15.80 \\
\hline 2004-05 & $\begin{array}{l}203853.29 \\
(51.72)\end{array}$ & $\begin{array}{l}180633.24 \\
(45.83)\end{array}$ & $\begin{array}{l}9650.67 \\
(2.45)\end{array}$ & $\begin{array}{l}394137.20 \\
(100 \%)\end{array}$ & 7.10 \\
\hline 2005-06 & $\begin{array}{l}218431.90 \\
(50.15)\end{array}$ & $\begin{array}{l}209285.40 \\
(48.05)\end{array}$ & $\begin{array}{l}7796.49 \\
(1.80)\end{array}$ & $\begin{array}{l}435513.79 \\
(100 \%)\end{array}$ & 10.49 \\
\hline 2006-07 & $\begin{array}{l}244373.61 \\
(47.95)\end{array}$ & $\begin{array}{l}256688.95 \\
(50.37)\end{array}$ & $\begin{array}{l}8574.90 \\
(1.68)\end{array}$ & $\begin{array}{l}509637.46 \\
(100 \%)\end{array}$ & 17.01 \\
\hline 2007-08 & $\begin{array}{l}257739.32 \\
(47.65)\end{array}$ & $\begin{array}{l}277538.55 \\
(51.32)\end{array}$ & $\begin{array}{l}5564.78 \\
(1.03)\end{array}$ & $\begin{array}{l}540842.65 \\
(100 \%)\end{array}$ & 6.12 \\
\hline 2008-09 & $\begin{array}{l}290140.34 \\
(45.60)\end{array}$ & $\begin{array}{l}341150.55 \\
(53.63)\end{array}$ & $\begin{array}{l}4918.02 \\
(0.77)\end{array}$ & $\begin{array}{l}636208.91 \\
(100 \%)\end{array}$ & 17.63 \\
\hline 2009-10 & $\begin{array}{l}362434.53 \\
(45.96)\end{array}$ & $\begin{array}{l}418263.53 \\
(53.04)\end{array}$ & $\begin{array}{l}7950.44 \\
(1.00)\end{array}$ & $\begin{array}{l}788648.50 \\
(100 \%)\end{array}$ & 23.96 \\
\hline 2010-11(RE) & $\begin{array}{l}434198.79 \\
(44.27)\end{array}$ & $\begin{array}{l}535122.66 \\
(54.55)\end{array}$ & $\begin{array}{l}11507.29 \\
(1.18)\end{array}$ & $\begin{array}{l}980828.74 \\
(100 \%)\end{array}$ & 24.36 \\
\hline 2011-12(BE) & $\begin{array}{l}477866.64 \\
(43.82)\end{array}$ & $\begin{array}{l}600978.80 \\
(55.09)\end{array}$ & $\begin{array}{l}11902.80 \\
(1.09)\end{array}$ & $\begin{array}{l}1090748.24 \\
(100 \%)\end{array}$ & 11.20 \\
\hline
\end{tabular}

Note: BE - Budget Estimates

RE - Revised Estimates

Figures in the parenthesis are percentage of total revenue receipts of states and calculated by the author.

Source: Various Issues of Indian Public Finance Statistics, Ministry of Finance.

Table-3 indicates the profile of revenue expenditure of states over the period from 1995-96 to 2011-12 (BE). The revenue expenditure of the states has increased from Rs. 64392.62 crore in 1995-96 to Rs. 1090748.24 crore in 2011-12 (BE). Non development expenditure constitutes 43.82 percent of the total revenue expenditure in 2011-12 (BE). The percentage share of development expenditure of states has increased from 54.11 percent in 1995-96 to 55.09 percent in 2011-12 (BE). Annual revenue expenditure growth rate has decreased from 15.78 percent in 1996-97 to
11.20 percent in 2011-12 (BE).

As the capital receipts cover up the shortfall between revenue receipts and total expenditure of the Government, now it turns towards the profile of capital receipts and capital expenditure. However, the distinctive feature of the capital receipts has been changing its pattern over a period of time. Table- 4 shows the growth of capital receipts of the State Governments. 
Table4. Capital Receipts of States

(Rs. in Crore)

\begin{tabular}{llll}
\hline Year & Capital Receipts & $\begin{array}{l}\text { Annual } \\
\text { Receipt } \\
\text { Rate }\end{array}$ & $\begin{array}{l}\text { Capital } \\
\text { Growth }\end{array}$ \\
\hline $1995-96$ & 16490.34 & - \\
$1996-97$ & 37570.83 & 127.83 \\
$1997-98$ & 48297.88 & 28.55 \\
$1998-99$ & 75859.39 & 57.06 \\
$1999-2000$ & 94180.41 & 24.15 \\
$2000-01$ & 92718.41 & -1.55 \\
$2001-02$ & 92808.57 & 0.09 \\
$2002-03$ & 128771.49 & 38.74 \\
$2003-04$ & 117885.82 & -8.45 \\
$2004-05$ & 124703.96 & 5.78 \\
$2005-06$ & 23401.50 & -81.23 \\
$2006-07$ & 88429.50 & 277.87 \\
$2007-08$ & 88429.50 & 0 \\
$2008-09$ & 132164.93 & 49.45 \\
$2009-10$ & 186210.39 & 40.89 \\
$2010-11$ (RE) & 180794.76 & -2.90 \\
$2011-12$ (BE) & 209694.69 & 15.98 \\
\hline
\end{tabular}

Note: BE - Budget Estimates $\quad$ RE - Revised Estimates

Source: Various Issues of Indian Public Finance Statistics, Ministry of

Finance.
Table-4 shows that the capital receipts of the states has increased has from Rs. 16490.34 crore in 1995-96 to Rs. 209694.69 crore in 2011-12 (BE) due to increase in interest receipts and increase in investment in the core sectors. Annual capital receipt growth rate has a fluctuating trend. It was 127.83 percent in 1996-97 and became 15.98 percent in 2011-12 (BE).This changing profile of capital receipts also had adverse impact on the Government finances, as both market borrowing and small savings are more expensive sources of capital receipts and invariably lead to higher interest burden in future if the returns on investment are not commensurate.

Table5. Capital Expenditure of States

(Rs. in Crore)

\begin{tabular}{|c|c|c|c|c|c|}
\hline Year & $\begin{array}{l}\text { Non Developmental } \\
\text { Expenditure (i) }\end{array}$ & $\begin{array}{l}\text { Developmental } \\
\text { Expenditure (ii) }\end{array}$ & $\begin{array}{l}\text { Loan Advances by } \\
\text { States and UT (Net) } \\
\text { (iii) }\end{array}$ & $\begin{array}{l}\text { Capital Expenditure } \\
\text { (i, ii, iii) }\end{array}$ & $\begin{array}{l}\text { Annual Capital } \\
\text { Expenditure } \\
\text { Growth Rate }\end{array}$ \\
\hline $1995-96$ & $\begin{array}{l}65.70 \\
(0.29)\end{array}$ & $\begin{array}{l}18416.57 \\
(79.18)\end{array}$ & $\begin{array}{l}4777.09 \\
(20.53)\end{array}$ & $\begin{array}{l}23259.36 \\
(100 \%)\end{array}$ & - \\
\hline $1996-97$ & $\begin{array}{l}94.76 \\
(0.44)\end{array}$ & $\begin{array}{l}17531.87 \\
(81.84)\end{array}$ & $\begin{array}{l}3797.28 \\
(17.72)\end{array}$ & $\begin{array}{l}21423.91 \\
(100 \%)\end{array}$ & -7.89 \\
\hline $1997-98$ & $\begin{array}{l}121.82 \\
(0.44)\end{array}$ & $\begin{array}{l}22773.14 \\
(81.37)\end{array}$ & $\begin{array}{l}5090.57 \\
(18.19)\end{array}$ & $\begin{array}{l}27985.53 \\
(100 \%)\end{array}$ & 30.62 \\
\hline $1998-99$ & $\begin{array}{l}203.20 \\
(0.65)\end{array}$ & $\begin{array}{l}22979.01 \\
(73.58)\end{array}$ & $\begin{array}{l}8047.45 \\
(25.77)\end{array}$ & $\begin{array}{l}31229.66 \\
(100 \%)\end{array}$ & 11.59 \\
\hline $1999-2000$ & $\begin{array}{l}378.02 \\
(1.00)\end{array}$ & $\begin{array}{l}25237.16 \\
(66.78)\end{array}$ & $\begin{array}{l}12176.05 \\
(32.22)\end{array}$ & $\begin{array}{l}37791.23 \\
(100 \%)\end{array}$ & 21.01 \\
\hline 2000-01 & $\begin{array}{l}252.58 \\
(0.73)\end{array}$ & $\begin{array}{l}29985.60 \\
(86.36)\end{array}$ & $\begin{array}{l}4484.82 \\
(12.91)\end{array}$ & $\begin{array}{l}34723.00 \\
(100 \%)\end{array}$ & -8.11 \\
\hline 2001-02 & $\begin{array}{l}515.49 \\
(1.44)\end{array}$ & $\begin{array}{l}30763.34 \\
(85.94)\end{array}$ & $\begin{array}{l}4514.93 \\
(12.62)\end{array}$ & $\begin{array}{l}35793.76 \\
(100 \%)\end{array}$ & 3.08 \\
\hline $2002-03$ & $\begin{array}{l}883.36 \\
(2.00)\end{array}$ & $\begin{array}{l}33029.79 \\
(74.79)\end{array}$ & $\begin{array}{l}10254.42 \\
(23.21)\end{array}$ & $\begin{array}{l}44167.57 \\
(100 \%)\end{array}$ & 23.39 \\
\hline 2003-04 & $\begin{array}{l}833.90 \\
(1.35)\end{array}$ & $\begin{array}{l}50241.95 \\
(81.07)\end{array}$ & $\begin{array}{l}10899.62 \\
(17.58)\end{array}$ & $\begin{array}{l}61975.47 \\
(100 \%)\end{array}$ & 40.31 \\
\hline 2004-05 & $\begin{array}{l}1298.29 \\
(1.84)\end{array}$ & $\begin{array}{l}58845.71 \\
(82.96)\end{array}$ & $\begin{array}{l}10784.84 \\
(15.20)\end{array}$ & $\begin{array}{l}70928.84 \\
(100 \%)\end{array}$ & 14.44 \\
\hline $2005-06$ & $\begin{array}{l}1038.36 \\
(1.19)\end{array}$ & $\begin{array}{l}77717.41 \\
(89.48)\end{array}$ & $\begin{array}{l}8099.90 \\
(9.33)\end{array}$ & $\begin{array}{l}86855.67 \\
(100 \%)\end{array}$ & 22.45 \\
\hline 2006-07 & $\begin{array}{l}1816.65 \\
(1.66)\end{array}$ & $\begin{array}{l}98378.12 \\
(89.69)\end{array}$ & $\begin{array}{l}9496.11 \\
(8.65)\end{array}$ & $\begin{array}{l}109690.88 \\
(100 \%)\end{array}$ & 26.29 \\
\hline $2007-08$ & $\begin{array}{l}2287.16 \\
(1.84)\end{array}$ & $\begin{array}{l}112717.32 \\
(90.71)\end{array}$ & $\begin{array}{l}9254.31 \\
(7.45)\end{array}$ & $\begin{array}{l}124258.79 \\
(100 \%)\end{array}$ & 13.28 \\
\hline 2008-09 & $\begin{array}{l}1980.40 \\
(1.39)\end{array}$ & $\begin{array}{l}133208.78 \\
(93.14)\end{array}$ & $\begin{array}{l}7832.32 \\
(5.47)\end{array}$ & $\begin{array}{l}143021.50 \\
(100 \%)\end{array}$ & 15.09 \\
\hline $2009-10$ & $\begin{array}{l}1462.53 \\
(0.88)\end{array}$ & $\begin{array}{l}151784.10 \\
(90.52)\end{array}$ & $\begin{array}{l}14433.52 \\
(8.60)\end{array}$ & $\begin{array}{l}167680.15 \\
(100 \%)\end{array}$ & 17.24 \\
\hline 2010-11(RE) & $\begin{array}{l}4591.33 \\
(2.37)\end{array}$ & $\begin{array}{l}170681.05 \\
(88.27)\end{array}$ & $\begin{array}{l}18100.41 \\
(9.36)\end{array}$ & $\begin{array}{l}193372.79 \\
(100 \%)\end{array}$ & 15.32 \\
\hline 2011-12(BE) & $\begin{array}{l}6779.12 \\
(2.98)\end{array}$ & $\begin{array}{l}2201251.65 \\
(96.95)\end{array}$ & $\begin{array}{l}19002.62 \\
(8.37)\end{array}$ & $\begin{array}{l}227033.39 \\
(100 \%)\end{array}$ & 17.40 \\
\hline
\end{tabular}

Note: BE - Budget Estimates

RE - Revised Estimates

Figures in parenthesis are percentage of total capital expenditure and calculated by the author.

Source: Various Issues of Indian Public Finance Statistics, Ministry of Finance. 
The expenditure on development activities comprise of major capital expenditure of the States. The impact of resource crunch and the need for fiscal correction has more often been in form of a compromise in the capital expenditure. The capital expenditure of the states has declined from Rs. 23259.36 crore in 1995-96 to Rs. 227033.39 crore in 2011-12 (BE). Non development expenditure constitutes 0.29 percent of the total capital expenditure in 2011-12 (BE). The percent share of development expenditure of states has increased from 79.18 percent in 1995-96 to 96.95 percent in 2011-12 (BE). The increasing trend of development expenditure is found in capital expenditure of the states as it is clear from Table-5. The annual capital expenditure growth rate increased from 7.89 percent in 1996-97 to 17.40 in 2011-12 (BE).

Table 6. Chain Index

\begin{tabular}{|c|c|c|c|c|c|c|c|c|}
\hline \multirow[b]{2}{*}{ Year } & \multicolumn{2}{|c|}{ Revenue Receipts } & \multicolumn{2}{|c|}{ Revenue Expenditure } & \multicolumn{2}{|c|}{ Capital receipts } & \multicolumn{2}{|c|}{ Capital Expenditure } \\
\hline & $\begin{array}{l}\text { Link } \\
\text { Relatives } \\
\end{array}$ & $\begin{array}{l}\text { Chain } \\
\text { Indices }\end{array}$ & $\begin{array}{l}\text { Link } \\
\text { Relatives } \\
\end{array}$ & $\begin{array}{l}\text { Chain } \\
\text { Indices }\end{array}$ & $\begin{array}{l}\text { Link } \\
\text { relatives }\end{array}$ & $\begin{array}{l}\text { Chain } \\
\text { Index }\end{array}$ & $\begin{array}{l}\text { Link } \\
\text { Relatives } \\
\end{array}$ & $\begin{array}{l}\text { Chain } \\
\text { Indices }\end{array}$ \\
\hline $1995-96$ & 100 & 100 & 100 & 100 & 100 & 100 & 100 & 100 \\
\hline 1996-97 & 111.26 & 111.26 & 115.78 & 115.78 & 227.83 & 227.83 & 92.10 & 92.10 \\
\hline $1997-98$ & 112.39 & 125.04 & 111.55 & 129.15 & 128.55 & 292.87 & 130.62 & 120.30 \\
\hline 1998-99 & 104.63 & 130.82 & 119.01 & 153.70 & 157.06 & 459.99 & 111.59 & 134.24 \\
\hline $1999-2000$ & 116.63 & 152.57 & 117.99 & 181.35 & 124.15 & 571.07 & 121.01 & 162.44 \\
\hline $2000-01$ & 110.29 & 168.26 & 106.71 & 193.52 & 98.44 & 562.16 & 91.88 & 149.25 \\
\hline 2001-02 & 112.04 & 188.53 & 112.30 & 217.32 & 100.09 & 562.77 & 103.08 & 153.85 \\
\hline 2002-03 & 106.06 & 199.95 & 104.03 & 226.08 & 138.74 & 780.65 & 123.39 & 189.84 \\
\hline 2003-04 & 117.23 & 234.40 & 115.80 & 261.80 & 91.54 & 714.61 & 140.31 & 266.36 \\
\hline 2004-05 & 116.48 & 273.03 & 107.10 & 280.39 & 105.78 & 755.91 & 114.44 & 304.82 \\
\hline 2005-06 & 122.01 & 333.13 & 110.49 & 309.81 & 18.76 & 141.80 & 122.45 & 373.26 \\
\hline 2006-07 & 124.05 & 413.25 & 117.01 & 362.50 & 377.87 & 535.85 & 126.29 & 471.39 \\
\hline 2007-08 & 109.28 & 451.60 & 106.12 & 384.69 & 100 & 535.85 & 113.28 & 533.99 \\
\hline 2008-09 & 110.60 & 499.47 & 117.63 & 452.51 & 149.45 & 800.83 & 115.09 & 614.57 \\
\hline $2009-10$ & 116.79 & 583.33 & 123.96 & 560.93 & 140.89 & 1128.30 & 117.24 & 720.53 \\
\hline 2010-11(RE) & 126.63 & 738.67 & 1245.36 & 697.58 & 97.09 & 1061.61 & 115.32 & 830.91 \\
\hline 2011-12(BE) & 115.57 & 853.68 & 111.20 & 775.71 & 115.98 & 1231.26 & 117.40 & 975.49 \\
\hline
\end{tabular}

In Table- 6 , on the basis of chain index value, the revenue receipts, revenue expenditure and capital expenditure shows increasing trend. But the lowest value of capital expenditure was noticed during the time-period 2005-06 in terms of link relatives $18.76 \%$. Upto $2004-05$, the chain index value of revenue expenditure was more than the chain index value of revenue receipts. But since 2005-06, the chain index value of revenue expenditure is less than the chain index value of revenue receipts. In all the years, the chain index value of capital expenditure is less than the chain index value of capital receipts.

Table 7. Mean, Standard Deviation and Coefficient of Variation

\begin{tabular}{lllll}
\hline & Revenue Receipts & Revenue Expenditure & Capital Receipts & Capital Expenditure \\
\hline Mean & 427923.14 & 446780.30 & 102259.55 & 84775.97 \\
S.D. & 299150.03 & 282482.72 & 55396.04 & 65116.70 \\
C.V. & 69.90 & 63.22 & 54.17 & 76.81 \\
\hline
\end{tabular}

On the basis of Coefficient of Variation (C.V.), if we compare the revenue receipts, revenue expenditure, capital receipts and capital expenditure, capital expenditure has recorded more variations i.e. 76.81 .

\section{Conclusion}

Based on our analysis of data with regard to deficit indicators, revenue receipts, revenue expenditure, capital receipts and capital expenditure, we found that there is a serious problem of growing fiscal imbalances at state level in terms of widening gap between revenue and expenditure. This is largely an outcome of the fact that in the fact of a limited resource base, the States had to cope with a significant growth in their committed expenditure. The crucial issue therefore is to bring out improvement in the State finance with a view to restructuring the expenditure in favour of development expenditure in order to enable a higher growth. The recent fiscal developments at State level put emphasis on the on-going fiscal and institutional reforms and seem to follow the path of reforms. For States, Thirteenth Finance Commission has suggested a revised fiscal roadmap to provide the basis for sustainable adjustment of public finances going forward. The Thirteenth Finance Commission has set a target of reducing fiscal deficit to 3\% of GDP for States latest by 2014-15. 


\section{References}

[1] Ahluwalia, M.S. (2000), "Economic Performance of States in Post Reforms Period", Economic and Political Weekly, May 6, pp. 1637-48.

[2] Bagchi, et al. (2002), "Fifty Years of Fiscal Federalism in India: An Appraisal" NIPFP Working Paper No.2.

[3] Balasubramanian, G. (2012), "Impact of Finance Commission Transfers on the Fiscal Responsibility of States in India: Evidence from Panel Data", Southern Economist, pp. $40-44$.

[4] Dasgupta, Zico (2012), "Development Expenditure of the States in the Post- Liberalisation Period", Economic and Political Weekly, August 25, pp. 64-73.

[5] Government of India: Indian Public Finance Statistics, Ministry of Finance, Various Issues.

[6] Kochhar, K. (2004), "Macro Economy Implications of the Fiscal Implication" paper presented at the IMF/ NIPFP Conference on Fiscal Policy in India, 16-17 January, 2004.

[7] Rangarajan, C. and Srivastava, D.K. (2005), "Fiscal Deficits and Government Debt in India: Implications for Growth and Stabilisation", NIPFP Working Paper No. 35/2005.

[8] Raikhy, N. (2006), "State Finances in India: Some Proposals for Reforms" in Srivastava, D.K. and Narasimhulu, M. (Ed), State Level Fiscal Reforms in the Indian Economy on behalf of Indian Economic Association, Deep \& Deep Publication, New Delhi.

[9] Rao, M. Govinda (1992), “A Proposal for State-level Budgetary Reforms", NIPFP, Working Paper No.19, New Delhi.

[10] Rao, M. Govinda (2002), "State Finances in India: Issues and Challenges", Economic and Political Weekly, August 3; pp. 3261-3271.

[11] Rao, M. Govinda and Rao, R. K. (2005), "Trends and Issues in Tax Policy and Reform in India", NIPFP, Working Paper No 1, November.

[12] Reserve Bank of India (2012), State Finances: A Study of Budgets of 2011-12.

[13] Singh, S.K.(2006), "State of State Finances in India: An Analysis" in Srivastava, D.K. and Narasimhulu, M. (Ed),State Level Fiscal Reforms in the Indian Economy on behalf of Indian Economic Association, Deep \& Deep Publication, New Delhi.

[14] Srivastava, D.K. (2009), "Finance Commission and the Southern States: Overview of Issues", Working Paper, 44

[15] Srivastava, D.K. and Rao, C.B. (2011), "Dependence of States on Central Transfer Aggregate and State wise Analysis", Working Paper, 59/2011.

[16] Vadra, R. (2010), "State Finances in India: Problems and Prospects" JM International Journal of Management Research, pp. 43-53. 